\title{
Science and Innovation Strategic Policy Plans for the 2020s (EU,AU,UK): Will They Prepare Us for the World in 2050?
}

\author{
Dr. Milly Perry ${ }^{1}$ \\ ${ }^{1}$ The Open University of Israel, Israel. \\ Correspondence: Dr. Milly Perry, the Open University of Israel, Israel.
}

Received: May 28, 2015

Accepted: June 12, 2015

Available online: June 25, 2015

doi:10.11114/aef.v2i3.909

URL: http://dx.doi.org/10.11114/aef.v2i3.909

\begin{abstract}
The world in 2050 will be very different from the world in which we currently live. An in-depth analysis suggests five main forces that will reshape the global economy and influence the "modus operandi" of the world in fifty years. These are defined as "the great rebalancing," "the productivity imperative," "the global grid," "pricing the planet," and "the market state." This paper is a theoretical comparative review, backed by hypotheses methods, to illustrate the conceptual framework of how and if national and international policy makers and stockholders are preparing their communities (countries) for the challenges of the future.

EU (2013) Horizon 2020 a major policy plan of the European Union which is built around the three focal pillars of "excellent science," "industrial leadership," and research to tackle "societal challenges," has decided to support research towards meeting seven broad challenges: Health; demographic changes and wellbeing; food security; sustainable agriculture and forestry; marine, maritime and inland water research; bio-economy; secure, clean, and efficient energy; smart, green, and integrated transport; climate action; environment, resource efficiency, and raw materials; inclusive, innovative, and reflective societies; and secure and innovative societies.

The United Kingdom (2014) is aiming at being foremost in science and business. They plan to achieve this by prioritizing, nurturing scientific talent, investing in scientific infrastructure, supporting research, and catalyzing innovation through participation in global science and innovation. They intend on realizing these goals by taking the lead in accelerating the pace and seizing new opportunities. Support is needed to accommodate and foster higher levels of collaboration between disciplines, sectors, institutions, people, and countries.

Australia (2014) declared the need for clear innovation priorities supported by a solid research foundation and strong linkages between business and research sectors, in order to increase the translation of knowledge into new products, processes and services. Also needed is a flexible workforce with the entrepreneurial skills to thrive in an environment of rapid technological change, and a regulatory environment that supports collaboration and creativity.

Are these national objectives consistent with 2050 world challenges?

What can we learn from national priorities and objectives? Are they driven by the science level and/or situation in a given country, or by previous investments in infrastructure and achievement status? Are they driven by geographic location or economic sustainability? Are the challenges common to all nations as global challenges? Are there any tools, strategy and solutions to meet those challenges? How will they influence science? And finally, does it reflect on science administration in this global world?
\end{abstract}

Keywords: science policy, 2020, 2050, economy, comparative analysis

\section{Introduction}

Government and government policy serve the community's future well-being and sustainability. Science policy should be compatible with global challenges, and should reflect an international global view that takes into consideration not only economic parameters, but social, ethical, and moral issues. Policy should be evidence-based; and have a sound, coherent strategy on which to base its assumptions, principles, and the models which shape it. An accountable leadership should be involved in predicting future influencing factors and looking ahead beyond the "here and now." Optimizing the effectiveness and efficiency of the eminent annual investment of public funds in science comes without 
saying. "Science policy must also address issues of appropriateness, of the connections between public investments in science and the social, economic and environmental outcomes those investments seek to achieve, and also of the appropriate role of science in a healthy democracy."'(Harris and Meyer, 2011. p.1).Instead of defining terminology (i.e. science, science policy etc.), this paper will focus on defining a structure and matrix in order to leverage our understanding and thinking tools for systematic analysis of science policies. This is particularly relevant to recognizing the challenges predicted for the world in 2050. Our perspective is expressed by Brooks' well-known notion (1996): Science policy is the role of government in decision-making that affects the conduct of science; and science, in return, provides evidence to enlarge the ground on which decisions are made.

As we would all like to believe, "In a perfect world, scientists collect facts, politicians develop policies based on those facts, legislators pass laws to implement these policies, and government agencies enforce the laws, most likely through regulations based on the same kind of facts. Because the laws, policies, and regulations are based on the truth, they work, and our problems are solved: efficiently, effectively, and economically."(Oreskes,2004).

This paper will present a number of projections regarding the world in 2050, and will analyze three national international policies of 2020 in order to conclude whether they will provide the right pathway, infrastructure and mental model to meet future changes in 2050.

\section{Method}

A comparative approach is often used in the study of society. Many disciplines have employed this method to understand phenomena in the fields of philosophy, anthropology, and political science, by comparing different cultures, processes, places, times and perspectives. Categories and classifications have been developed to form insights and clear understandings of phenomena with shared solutions and rational. In a global world, cross-cultural analyses and comparisons help researchers prepare the foundation for new understandings of society, technology, and economics. Over time, an interdisciplinary approach has gained centrality and importance. This is especially true today, in a world in which challenges involve components from various fields, and complexity is significant. This reality demands complex synthesis and analysis, as well as additional scientists to deal with similar challenges in a shorter period of time. Collaboration in, and between, disciplines is essential.

\section{2050 Forecast}

Economic and international forecast analysis is an inherently challenging and intriguing expertise. Several established global consulting groups, think-tanks, global organizations, and forums engaged with government policy and stakeholders in a global context, including OECD, The Economic Forum, and World Bank are involved with this kind of research. International forecast analysis is a well-known practice in a few prestigious global consultancy groups, such as $\mathrm{PwC}$, McKinsey \& Company, etc.

PwC 2050 reports that the world economy is projected to grow at an average rate of just over 3\% per annum from 2011 to 2050 , doubling in size by 2032, and nearly doubling again by 2050. McKinsey \& Company, a global consulting group that practices forecasts, has been drawing key global trends that will define the world in 2050. Based on ongoing data collection, interviews, assumptions, and past forecasts, they have identified five forces that will crystalize tomorrow's world. The world between 2030 and 2050 will launch a third industrial revolution with several new trends and features, based on a growing reliance on information and communication systems.

These forecast five forces are "the great rebalancing," "the productivity imperative," "the global grid," "pricing the planet," and "the market state."

1. According to "the great rebalancing," emerging-market countries will, for the first time ever, contribute more growth than developed countries. This phenomenon will create a new middle-class market, as well as consumers, and will also drive profound innovations in products and market infrastructure.

\section{Urbanization}

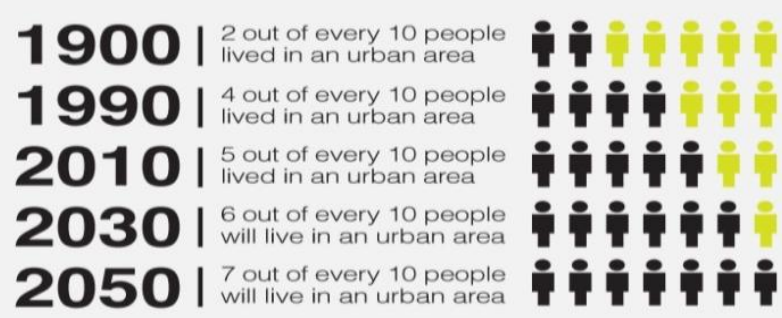

Figure No. 1 Urbanization (UDconnect Desing .,2013) 
Researchers (Foure,J, Benassy-Quere,A \& Fontagne,L, 2010, p.1.) suggest that "new" countries will collectively overtake the EU28 global power in 2030. Countries such as Colombia, Indonesia, Nigeria, South Africa, and Turkey will become vital to the global economy. Meanwhile, the economies of Europe, Japan, and Russia are likely to continue their relative declines. "China could account for $28 \%$ of the world economy in 2050 , which would be much more than the United States (14\%), India (12\%), the European Union (11\%) and Japan (3\%). They also suggest that China could overtake the United States around 2025. However, in terms of standard-of-living, measured through GDP per capita in purchasing power parity, only China would be close to achieving convergence to the US level, and only at the end of the simulation period. (Foure, Benassy-Quere \& Fontagne, 2010, p.5)" There is a growing centrality to cities over countries, in which approximately 440 cities will be producing $60 \%$ of the GDP.

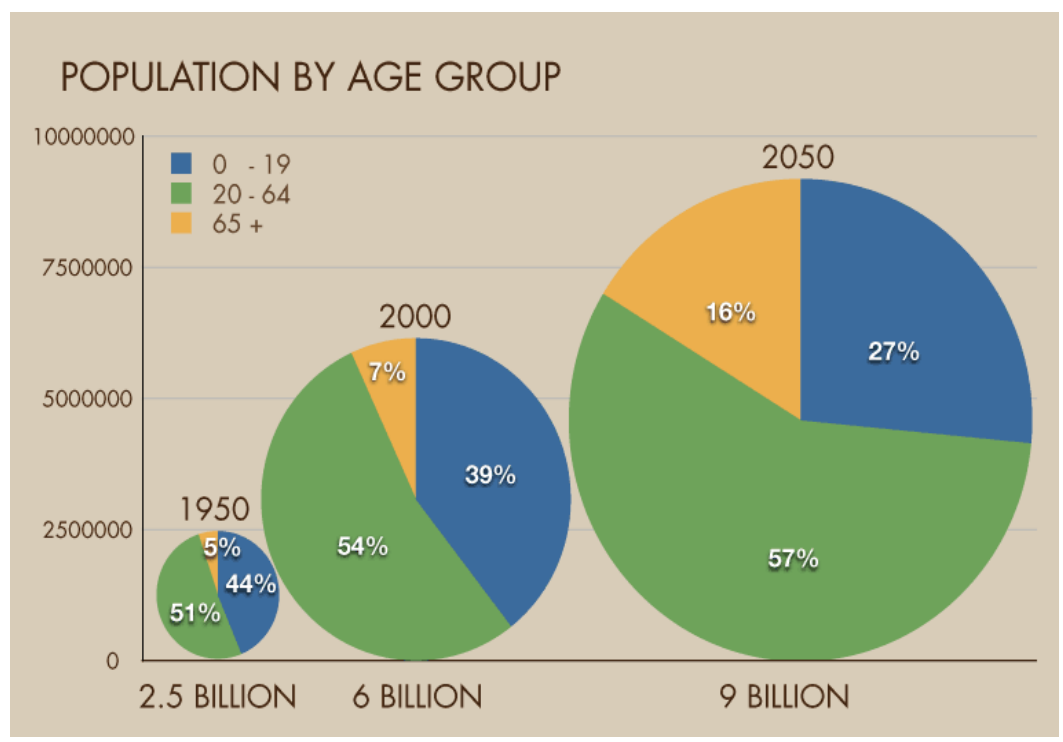

Figure No. 2 Population by age group (culture geography,freeweb.com)

2. In order to power economic growth in a developed-world economy, there is a substantial need for generating productivity. According to "The productivity imperative," labor productivity and talent management are both driven by, and drive, economic needs. Innovation and technology, as the main vehicles for productivity, will be reinforced and gain prominence in the eyes of policy makers, as well as in the private markets. As McKinsey (2015) suggests, " Technology will continue to materially reshape consumer awareness, choice, and interactivity models, and companies should be striving to tap the power of technology to improve their competitive advantage."
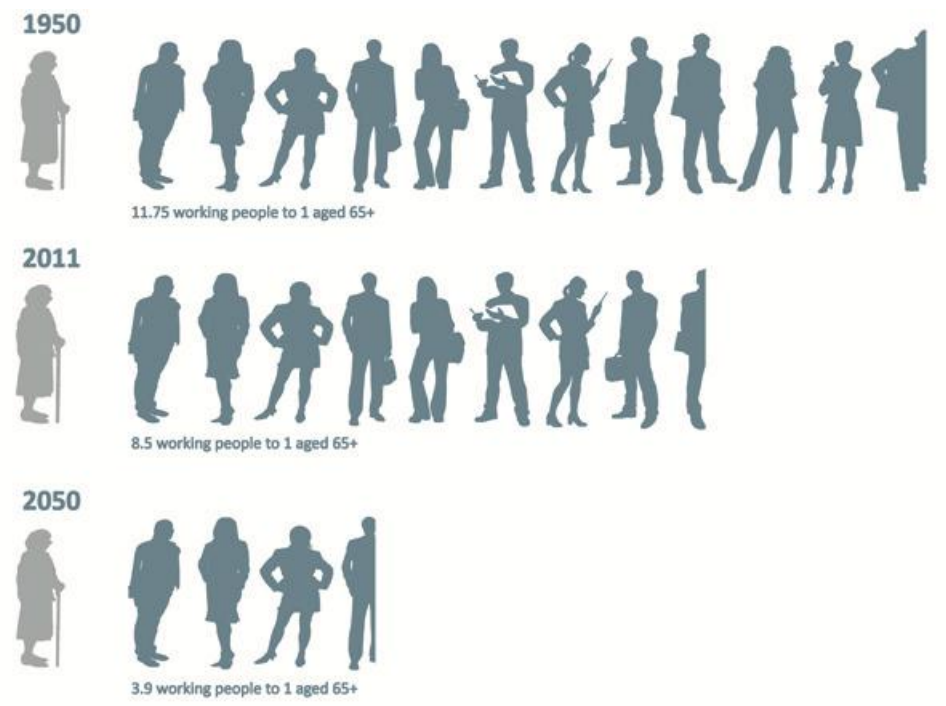

Figure No. 3: Working people vs. retired (UN report 1950-2050)

3. "The global grid" represents the strengthened connectivity and global flow of goods, information, and capital. The global economy is growing ever more connected. Complex interactions of capital, people, and information are creating non-stop networks that overcome geographical, social, national, and other top-down boundaries and hurdles. The power 
of technology, big data, knowledge, and this active grid gives broad operational leeway for new business models and opportunities. The network of non-state actors, organized crime, and urban violence will increase in megacities.

With better access to disruptive technologies, cyber systems experts would recognize valuable talent that might serve a variety of interests and values, and not necessarily only the normative ones. This grid emphasizes the term VOCA, standing for "volatile, uncertain, complex and ambiguous." This term describes a world that will become more fragile and unpredictable fiscally, socially, politically, and with regard to natural resources and forces.

4. The third force, "Pricing the planet," refers to natural resources management. The next decade will see an increased focus on resource productivity, the emergence of substantial clean-tech industries, and regulatory initiatives. A clear rising curve of demand for more natural resources will clash with deteriorating resource availability, and the pressure and moral obligation of protecting those resources for the next generation. Social accountability and the constraints of a zero-sum game will increase the probability of political instabilities and international conflicts.

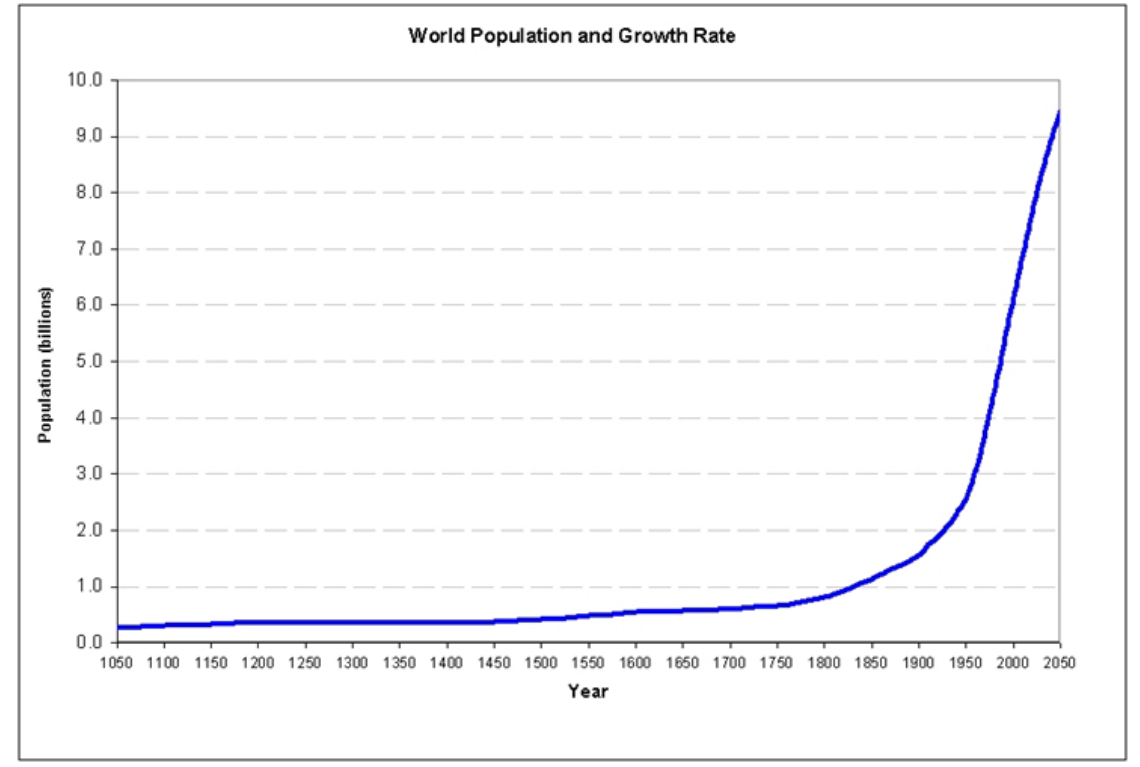

Chart No. 1: World Population and Growth Rate

5. The increasing role of government in becoming a commanding force of change reflects the "market state." The national and geo-political requirements for society's security and economic needs usually contradict the demands of growth maintenance. To ensure growth maintenance, governments must cope with internal and external political and international pressures. Globalization adds additional challenges for distinctly national entities, who will need to govern in an increasingly globalized world. Emerging and developing countries will strive to influence key multilateral institutions such as the UN, the IMF, and the World Bank, but they will still need to develop their own concepts and vision in order to replace the dominance of the Western world.

In the following paragraphs we will present the national and international policy plans of the European Commission, the United Kingdom, and Australia, comparing their principals to the 2050 forecast five forces, in order to recognize the similarities between them.

\section{National Policies Analysis}

\subsection{European Commission - Targets and Challenges}

EC FP7 monitoring reports (2013) present many indicators for the success of the science and innovation policy. The indicators point out that $17 \%$ of all participants in signed grant agreements were SMEs, and the fact that over a period of five years it funded projects with participant organizations from as many as 170 countries. Outside the group of EU and Associated Countries the biggest participants are the USA, Russia, China, Brazil and India. It is estimated that 21.1\% of contact persons for scientific aspects in FP7 funded projects are female in 3.220 projects. Achievements of the Framework Program are over 16.000 publications, and 505 patent applications. We believe the criteria of success, measured in comparison to previous years are not satisfactory. It may be more imperative to compare the achievement against targets and a world-changing global view.

According to a EU policy paper (EUROPE 2020 A strategy ,2010), is still facing an average growth rate that has been structurally lower than that of the main economic partners, lower levels of investment in R\&D and innovation, 
insufficient use of information and communications technologies, reluctance in some parts of societies to embrace innovation, barriers to market access and a less dynamic business environment. In spite of progress, Europe's employment rates - at $69 \%$ on average for those aged 20-64 - are still significantly lower than in other parts of the world. Only $63 \%$ of women are employed, compared to $76 \%$ of men. Only $46 \%$ of older workers (55-64) are employed, compared to over $62 \%$ in the US and Japan. Demographic ageing is accelerating. The EU's active population has started to shrink, from 2013/2014. The number of people aged 60 and over is now increasing twice as fast as it did before 2007 - by about two million every year, compared to one million previously. The combination of a smaller working population and a higher share of retired people will place additional strains on the welfare systems.

Measurable policy targets are notified in several fields: 75 per cent of the population aged 20-64 should be employed. 3\% of the EU's GDP should be invested in R\&D, The "20/20/20" climate/energy targets should be met (including an increase to $30 \%$ of emissions reduction if the conditions are right), The share of early school leavers should be under $10 \%$, and at least $40 \%$ of the younger generation should have a tertiary degree and 20 million fewer people should be at risk of poverty (EUROPE 2020 A strategy for smart, sustainable and inclusive growth, 2010).

Table No. 1 - EC Targets

\begin{tabular}{|c|c|c|}
\hline \multicolumn{3}{|c|}{ HEADLINE TARGETS } \\
\hline \multirow{5}{*}{\multicolumn{3}{|c|}{$\begin{array}{l}\text { - Raise the employment rate of the population aged } 20-64 \text { from the current } 69 \% \text { to at least } 75 \% \text {. } \\
\text { - Achieve the target of investing } 3 \% \text { of GDP in R\&D in particular by improving the conditions for R\&D investment by the private sector, and develop a } \\
\text { new indicator to track innovation. } \\
\text { - Reduce greenhouse gas emissions by at least } 20 \% \text { compared to } 1990 \text { levels or by } 30 \% \text { if the conditions are right, increase the share of renewable energy } \\
\text { in our final energy consumption to } 20 \% \text {, and achieve a } 20 \% \text { increase in energy efficiency. } \\
\text { - Reduce the share of early school leavers to } 10 \% \text { from the current } 15 \% \text { and increase the share of the population aged } 30-34 \text { having completed tertiary } \\
\text { education from } 31 \% \text { to at least } 40 \% \text {. } \\
\text { - Reduce the number of Europeans living below national poverty lines by } 25 \%, \text { lifting } 20 \text { million people out of poverty. }\end{array}$}} \\
\hline & & \\
\hline & & \\
\hline & & \\
\hline & & \\
\hline SMART GROWTH & SUSTAINABLE GROWTH & INCLUSTVE GROWTH \\
\hline INNOVATION & \multirow{4}{*}{$\begin{array}{l}\text { CLIMATE, ENERGY AND MOBILITY } \\
\text { EU flagship initiative "Resource efficient } \\
\text { Europe" to help decouple economic growth from } \\
\text { the use of resources, by decarbonising our } \\
\text { economy, increasing the use of renewable sources, } \\
\text { modernising our transport sector and promoting } \\
\text { energy efficiency. }\end{array}$} & \multirow{4}{*}{$\begin{array}{l}\text { EMPLOYMENT AND SKILLS } \\
\text { EU flagship initiative "An agenda for new skills } \\
\text { and jobs" to modernise labour markets by } \\
\text { facilitating labour mobility and the development } \\
\text { of skills throughout the lifecycle with a view to } \\
\text { increase labour participation and better match } \\
\text { labour supply and demand. }\end{array}$} \\
\hline $\begin{array}{l}\text { EU flagship initiative "Innovation Union" to } \\
\text { improve framework conditions and access to } \\
\text { finance for research and innovation so as to } \\
\text { strengthen the innovation chain and boost levels } \\
\text { of investment throughout the Union. }\end{array}$ & & \\
\hline \multirow{4}{*}{$\begin{array}{l}\text { EDUCATION } \\
\text { EU flagship initiative "Youth on the move" to } \\
\text { enhance the performance of education systems } \\
\text { and to reinforce the international attractiveness of } \\
\text { Europe's higher education. }\end{array}$} & & \\
\hline & & \\
\hline & \multirow{3}{*}{$\begin{array}{l}\text { COMPETITIVENESS } \\
\text { EU flagship initiative "An industrial policy for } \\
\text { the globalisation era" to improve the business } \\
\text { environment, especially for SMEs, and to support } \\
\text { the development of a strong and sustainable } \\
\text { industrial base able to compete globally. }\end{array}$} & \multirow{3}{*}{$\begin{array}{l}\text { FIGHTING POVERTY } \\
\text { EU flagship initiative "European platform } \\
\text { against poverty" to ensure social and territorial } \\
\text { cohesion such that the benefits of growth and jobs } \\
\text { are widely shared and people experiencing } \\
\text { poverty and social exclusion are enabled to live in } \\
\text { dignity and take an active part in society. }\end{array}$} \\
\hline & & \\
\hline $\begin{array}{l}\text { DIGITAL SOCIETY } \\
\text { EU flagship initiative "A digital agenda for } \\
\text { Europe" to speed up the roll-out of high-speed } \\
\text { internet and reap the benefits of a digital single } \\
\text { market for households and firms. }\end{array}$ & & \\
\hline
\end{tabular}

It seems the European Policy attempts to tackle all challenges at the same time; it targets a vast variety of issues with no clear priority regarding importance, significance, emergency or the cohesiveness and adaptation to the national level of the policy fields. An updated review (Guardian, 2015. p.1) regarding Europe's present concerns reveals that Europe is facing the triple challenge of mass movements of people within its citizens, confronting unexpected Russian aggression, and repeated Islamist extremism. It seems that despite challenges that are well defined and declared, "Most European states have not begun to face up to their responsibilities in dealing with mass migration and tackling the roots of the religious extremism that often causes displacement." Regarding the five forces, it seems that "the great rebalancing" is acknowledged but does not attract much attention, "the productivity imperative" is gaining resources and focus in ICT and information technology infrastructure, mainly for the benefit of productivity and the urge to strengthen the damaged "innovation muscle" that differentiates Europe from its US allies. "The global grid," "pricing the planet," and "the market state" have surrendered to the present fight against poverty, unemployment and political fragmentation.

Spagnol (2014) indicates that The EU as a global economy and the cradle of human rights and democracy should have been virtue for international peace. In reality, Europe is still at a tactical level instead of a strategic one. One could expect European strategy (geopolitical and intellectual) to be able to mediate between emerging countries (Brazil, Russia, India, China and South Africa (BRICS) and to maintain liberal global order, but it has not become the reality.

\subsection{United Kingdom}

As presented to Parliament by the Minister of State for Universities, Science and Cities, and by the Secretary of State for Business, Innovation and Skills, "Our Plan for Growth: Science and Innovation" in December 2014, the British policy plan for achievement declares six elements: Deciding priorities, nurturing scientific talent, investing in our 
scientific infrastructure, supporting research, catalyzing innovation, participating in global science and innovation, composed of (p.5):

1. the importance of achieving excellence;

2. the imperative to operate at a quickening pace and show agility to seize new opportunities;

3. the need to accommodate and foster higher levels of collaboration between disciplines, sectors, institutions, people and countries;

4. the need to recognize the importance of place, where people and organizations benefit from mutual proximity;

5. the modern demand for openness and engagement with the world

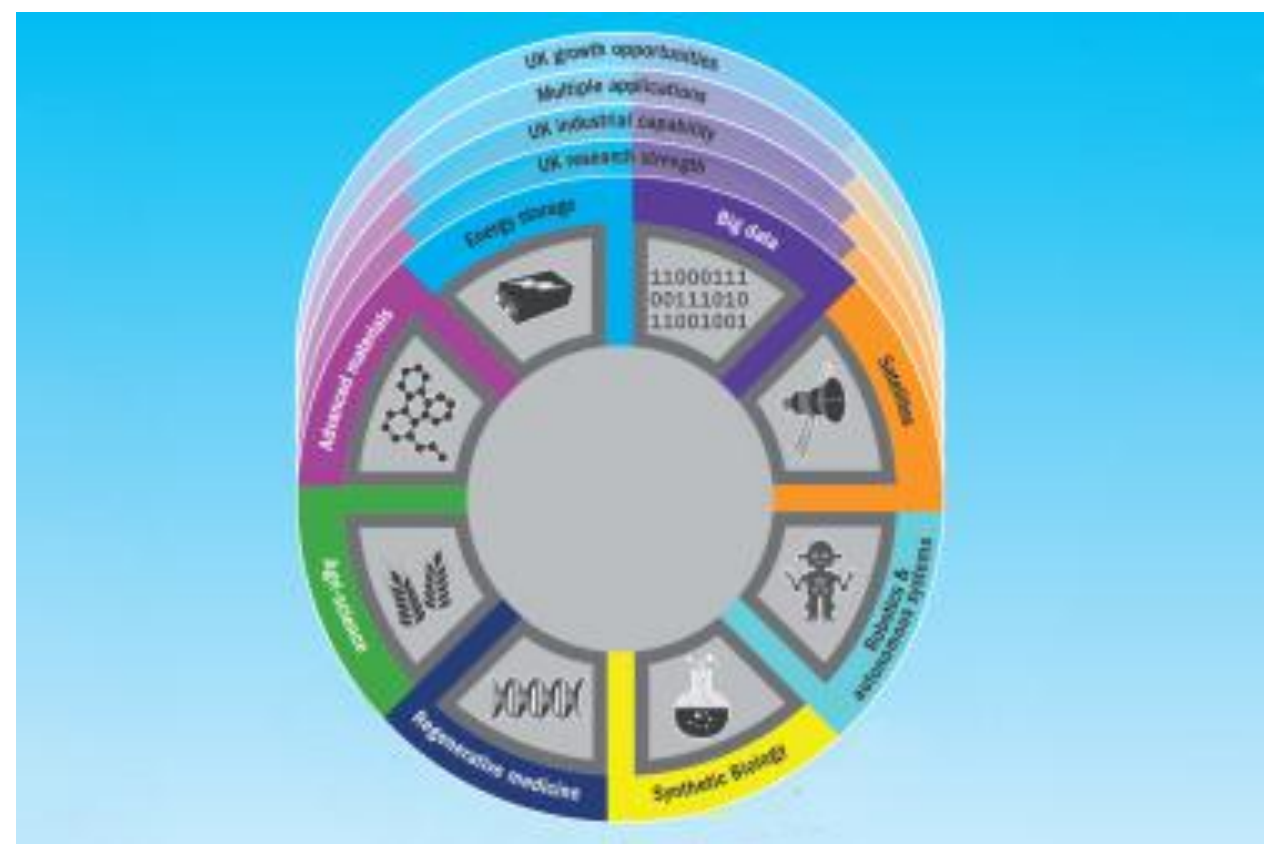

Figure No.4: UK Eight Great Technologies

The UK has defined eight great technologies in which it is set to be global leader.

Under the title of "Investing in our scientific infrastructure," the plan specifies budget allocation for the following main fields:

- $£ 235$ million in the Sir Henry Royce Institute for advanced materials.

- $£ 113$ million towards big data at the Hartree Centre, Daresbury.

- $£ 95$ million for European Space Agency programs, including Britain’s lead role in the next European Rover mission to Mars.

- $\quad £ 31$ million for a new Energy Security and Innovation Observing System, including a Subsurface Center at the former Shell site in Cheshire.

- $\quad £ 60$ million to extend the capabilities of the National Nuclear Users Facility.

- $£ 20$ million towards an innovation center on ageing, in Newcastle.

- $\quad £ 42$ million Alan Turing Institute will have its headquarters at the British Library.

In order to see the priorities, the scientific infrastructure planned budgets are displayed in the following chart: 


\section{BUDGET in million $f$}

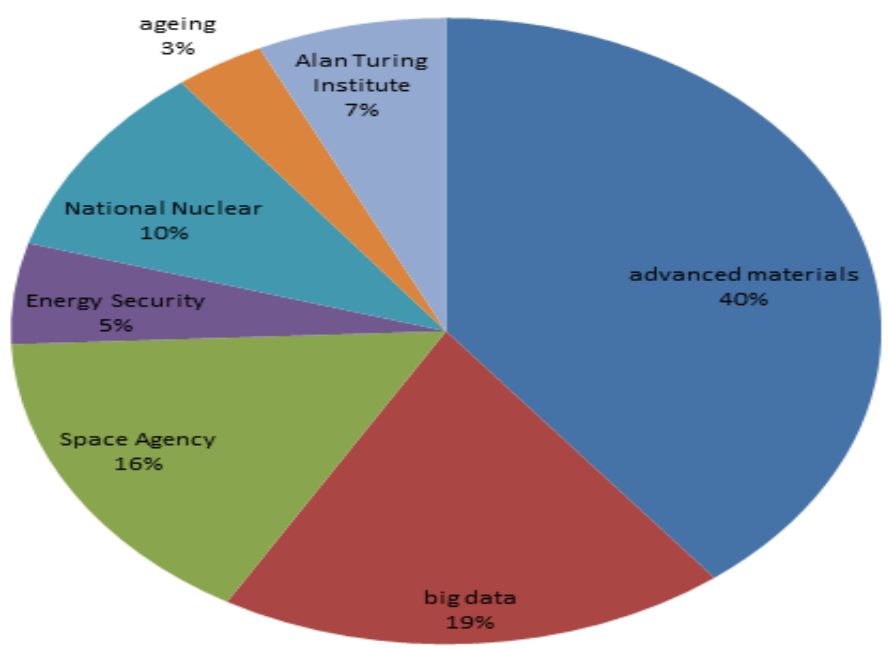

Chart No. 2 Budget in Million Pound

As one can see, all the budgeted fields are important, but only few are represented in the five future forces. Aging for instance, has been awarded the smallest budget, although it is one of the main forces of the future. "The market state" and "the great rebalancing," do not have any representation in the budgeted fields, or policy priorities. "The productivity imperative," and "the global grid," are budgets under the Allen Turing institute big data (about 26\%)."Pricing the planet," is the largest priority (55\%) under advances materials, national nuclear and energy.

\subsection{Australia}

A policy paper published in 2014 by the chief scientist of the Australian Government, titled "Australian Future" declared that Australia is the only country in the OECD not to have a current national strategy that bears on science and/or technology and/or innovation. This policy paper acknowledges that Australian "neighbors" such as India, China, Indonesia and Singapore all have strategies for 2015 or beyond. The science and technology policies have suffered from a "lack of coordination, misdirected effort, instability and duplication."(p.10). Australian policy makers point out that policy and program responsibility has been diffuse among agencies. The science, research and innovation investment reported in 2012-13 - amounting to approximately $\$ 8.6$ billion, was spread across a suite of programs in 13 separate portfolios. Some of these measures are united under shared strategic goals, but many are not. This led to ranking Australia 81 st as a converter of raw innovation capability into the outputs business needs. The current policy plan aims at four pillars:

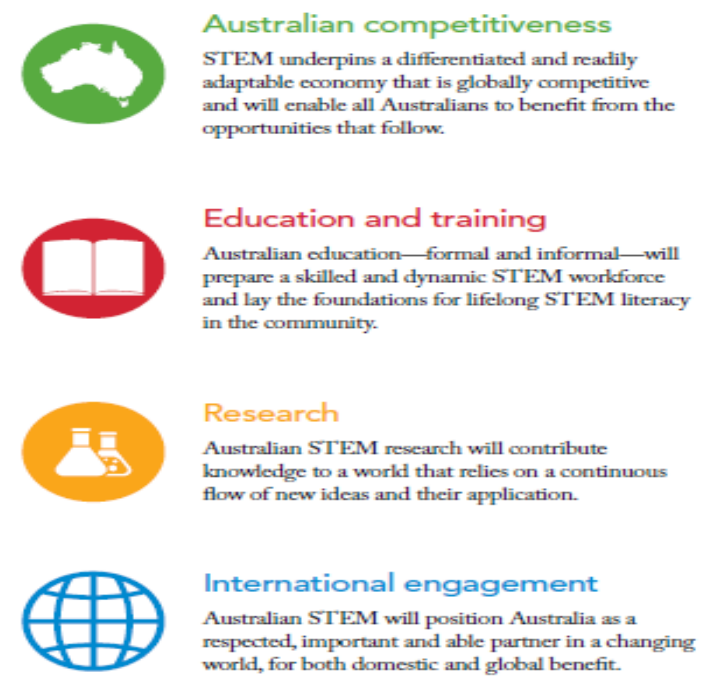

Figure No. 5 Australia - Four Priorities 
The main principles for the new policy are the follows: Competitiveness, that would lead by STEM (science, technology, engineering and mathematics) underpinning a differentiated and readily adaptable economy guided by global competitive. Education and training, both formal and informal, will prepare a skilled and dynamic STEM workforce, using lifelong tools. Research will contribute knowledge, new ideas and their application. International engagement will position Australia as a respected, important partner in a changing world.

Before entering budget allocations and national priories or essential fields of balancing, it is clear that the policy target 2015 challenges, or in an optimistic view, 2020's challenges. None of the far future forecasts related to 2050 are on the agenda to begin with. It is clear that Australia needs to dedicate its policy towards closing the gap with the current state of the western world in order to be capable of tackling the large challenges of the far future. Unless Australia progresses in the STEM targets, Its policymakers' managerial attention, efforts and resources will not be appropriate for "frog leaping" towards processing a systematic analysis for the future five forces forecast.

\section{Conclusion and Summary}

In summarizing the national policies compared to future forecast challenges, one can see that the national policies are lacking the "future big picture" in general, which is not surprising; they lack the tools to cope and face challenges them selves. The policies of 2020 are tackling today's challenges, the present societal and economic problems, and definitely not those of the distant future.

Table No. 2: Matching Policy and Forecast

\begin{tabular}{llll}
\hline $\begin{array}{l}\text { Forecast } \\
\text { Policy }\end{array}$ & EU & AU & UK \\
\hline Great rebalancing & X & X & X \\
Productivity imperative & V & X & V \\
Global grid & V & V & V \\
Pricing the planet & V & X & V \\
Market state & X & X & X \\
\hline
\end{tabular}

This paper attempted, to answer some questions by analyzing national policy plans and tackling them with the 2025 forecast. Are these national objectives consistent with 2050 world challenges? As we presented only a partial list of forecast forces are match with the current science and innovation policies. We have seen policies that include so many priorities that fail to influence the essence of future challenges (EC).

There is no doubt that national priorities and objectives are driven by the level of science and status of a given country. We can see that the UK aims much higher than the EC or AU. In the AU case study, we can see that the priorities are cut out of the current STEM level, and are aiming to reach the western economies, to decrease the gap, long before they can aim at future challenges. Geographic location or economic sustainability should influence the policy plans, as to our assumption, evidences lead to the fact that AU, for instance, although is a "neighbor" of the raising economies do not take this advantage for developing policy in the "region". Many of the challenges are global and common to all nations, but the way in which each nation or international (EC) relates to those challenges of course varies from country to country.

This analysis clearly shows that tools, strategies and solutions to meet challenges are common and not "innovative." They are explicitly influenced by one country to the other, affected by international organizations which practice international benchmark and know-how sharing. In many cases, this contributes to developing national policy, but in other cases it preserves "old tricks" for a totally new game.

My main reservation of the policy plans and forecast is that none of them can clearly say, that neither in 2020 nor, regrettably, in 2050 is there any evidence of a role for research administration and management wisdom. As in the EC FP7, and Horizon 2020, no efforts, resources or know-how are granted to this profession. As in past years, today we still need to choose our strategies, share with colleagues, and manage our knowledge and wisdom, thus preparing ourselves and our organizations for the future, without the benefit of the policymakers' managerial attention or recognition.

\section{Reference}

Bisson, P., Stephenson, E., \& Viguerie S, P. (2010). Global forces: An introduction. McKinsey Quarterly. U. S.

Brooks, H. (1996). The evolution of U.S. science policy.In Technology, R\&D, and the economy, edited by L. R. Bruce and C. E. Barfield, 14-149.Washington, DC: Brookings Institution.

Dobbs, R, Manyika, J., \& Woetzel, J. (2015). The Four global forces breaking all the trends. McKinsey \& Company, April 2015. 
Dye, R., \& Stephenson, E (2010). Five forces reshaping the global economy. McKinsey Quarterly. US.

EUROPE 2020 A strategy for smart, sustainable and inclusive growt (2010).

http://eur-lex.europa.eu/legal-content/EN/TXT/?uri=celex:52010DC2020

Harris, P., \& Meyer, R. (2011). Science policy Beyond budgets and breakthroughs: Discussion paper on enhancing Australian government sciences policy.

Horizon 2020- the EU's new research and innovation program. (2013). European Commission.

Foure, J, Benassay-Quere, A., \& Lionel, F. (2010). The world economy in 2050: a tentative picture, CEPII Working paper, 2010-27

Joining Forces collaboration and leadership for Sustainability. (2015). MIT Sloan management review, BCG and United Nation global compact.

Our plan for growth: science and innovation. Department of Business innovation and skills. (2014). U. K.

Oreskes, N. (2004). Science and public policy: what's proof got to do with it? Environmental Science \& Policy 7 (2004) 369-383, 370

PEW research center. (2014).

Recommendation on German Science Policy in the European Research Area. (2010) German Council of Science and Humanities.Science, technology, engineering and mathematics: Australia's future (2014). Australian Government, Chief Scientist.

Sixth FP7 Monitoring Report. MONITORING REPORT 2012 (2013). The DG RTD Evaluation, EC. Brussels.

Spagnol, G. (2014). Global Challenges: a sneak peek into the future. Academia Diplomatica European Institute European des Relations Internationals. Brussels. Belgium.

The future of science, technology and innovation policies. OECD. (2014). Paris.

The Observer view on the future of Europe Observer editorial (2015).The Guardian.UK.

World in 2050. (2013). PwC Economics. The BRIC and beyond: prospects, challenges and opportunities.

\section{(cc) BY}

This work is licensed under a Creative Commons Attribution 3.0 License. 